\title{
PENGARUH STRATEGI PEMBELAJARAN POINT COUNTERPOINT TERHADAP HASIL BELAJAR MATA PELAJARAN FIQH SISWA MAN KARANGGEDE TAHUN 2014/2015
}

\author{
Musta'an \\ USAHID Surakarta \\ Email:musta'an57@gmail.com
}

This study is an experimental research conducted at MAN Karanggede. The population in this study were students of class XI which totaled 200, with purposive sampling technique obtained a sample of 90 students. The samples were divided into two groups, the first group as a control group and a second group class as a class experiment. Data was collected by the method of testing and documentation. Test validity consists of 35 items, 31 items known to valid and invalid 4 items. Of the 31 items were valid, the validity of the lowest known 0.399 and 0.722 and the highest validity reliabelitas 0.91. Data prior to analysis prerequisite test, normality test, homogeneity test, tests of balance and analyzed using statistical t-test formula.

From the data analysis is concluded that control class (using conventional methods) reached an average value of 48.62 by the level of learning outcomes in the category were as many as 16 students or $35.56 \%$ are located at intervals of 13-15. While the experimental group (using learning strategies point counterpoint) reached an average value of 71.97 by the level of learning outcomes in high category as many as 10 students or $22.22 \%$ are located at intervals of 22-25. Of the average showed a difference of 23.35. While the results of different test variable levels of learning outcomes fiqh in control class with experimental class obtained $t$ count (5.721)> t table (2.000), it means Ha accepted, so there are significant learning strategy point counterpoint to the results of study subjects fiqh students MAN Karanggede school year $2014 / 2015$.

Keywords: Learning Strategies Point Counterpoint, Fiqh Learning Outcomes

\section{PENDAHULUAN}

Pendidikan merupakan suatu hal yang tidak bisa dilepaskan dari manusia karena pendidikan merupakan salah satu komponen yang sangat penting bagi kehidupan seseorang, baik dalam kehidupan keluarga, bermasyarakat maupun bernegara. Kemajuan pembangunan di suatu negara baik lahir maupun batin dapat di capai melalui pendidikan yang terarah, teratur dan berkesinambungan. Dengan demikian akan tercipta manusia yang cerdas, terampil, berwawasan luas, disiplin, bertakwa serta bertanggung jawab di dalam kehidupan.

Pendidikan, baik formal maupun informal memiliki kedudukan yang sangat penting dan memegang peranan besar dalam lingkupnya masing-masing, sehingga diperlukan manajemen strategi yang baik. Salah satu pendidikan formal adalah sekolah yang merupakan salah tempat mentransformasikan berbagai ilmu, informasi, unsur sosial, dan budaya melalui 
suatu proses pembelajaran. Sekolah juga merupakan salah satu tempat para siswa untuk berinteraksi dan memperoleh pengalaman baru. Menurut Syafaruddin dan Irwan (2005: 6) sekolah merupakan tempat berlangsungnya proses sosialisasi anak melalui pengajaran ilmu pengetahuan dan penanaman nilai yang bersumber dari kurikulum.

Dalam dunia pendidikan, fiqh merupakan suatu mata pelajaran yang sangat penting untuk bisa dipahami oleh siswa, karena mata pelajaran fiqh adalah salah satu mata pelajaran yang membahas ajaran agama Islam dari segi syariat Islam tentang cara-cara manusia melaksanakan ibadah kepada Allah dan mengatur kehidupannya (Depag, 2007: 24). Adanya mata pelajaran fiqh di sekolah-sekolah diharapkan siswa dapat memahami dengan baik ajaran-ajaran yang ada dalam syariat Islam sehingga mereka dapat melaksanakan ibadah dengan baik, sesuai dengan aturanaturan yang telah ditentukan didalam kehidupan nyata.

Untuk menanamkan pemahaman yang baik terhadap siswa berkenaan mata pelajaran fiqh bukanlah suatu hal yang dapat dianggap mudah ataupun sepele. Fiqh merupakan suatu mata pelajaran yang membutuhkan banyak penelaahan karena cakapan materi yang isinya selalu berkembang sesuai dengan perkembangan zaman. Seorang guru harus mempunyai ketrampilan yang kreatif dalam proses pembelajaran dan guru juga dituntut memiliki wawasan yang luas berkenaan masalah-masalah fiqh yang sedang berkembang.

\section{Tujuan}

Tujuan penelitian ini antara lain untuk mengetahui hasil belajar siswa kelas XI pada mata pelajaran fiqh di MAN Karanggede yang dalam proses pembelajarannya menggunakan metode konvensional. Untuk mengetahui hasil belajar siswa kelas XI pada mata pelajaran fiqh di MAN Karanggede yang dalam proses pembelajarannya menggunakan strategi pembelajaran Point Counterpoint. Kemudian untuk mengetahui ada tidaknya pengaruh strategi pembelajaran Point Counterpoint terhadap hasil belajar siswa kelas XI pada mata pelajaran fiqh di MAN Karanggede.

\section{KAJIAN PUSTAKA}

\section{Strategi Pembelajaran Point Counterpoint}

Strategi berasal dari bahasa yunani strategos yang berarti jendral atau panglima, sehingga strategi diartikan sebagai ilmu kejendralan atau ilmu kepanglimaan. Strategi dalam pengertian kemiliteran ini berarti cara penggunaan seluruh kekuatan militer untuk mencapai tujuan perang. Dalam perkembangan selanjutnya strategi diterapkan dalam dunia pendidikan terutama dalam pembelajaran. Strategi dalam dunia pembelajaran diartikan sebagai seni membawakan pengajaran dikelas sedemikian rupa sehingga tujuan yang telah diterapkan dapat dicapai secara efektif dan efisien (W. Gulo, 2002: 1-2). Wina Sanjaya (2008: 61) mengatakan bahwa strategi pembelajaran adalah suatu set materi dan prosedur pembelajaran yang 
digunakan secara bersama-sama untuk mencapai tujuan tertentu.

Sedangkan strategi pembelajaran

Point Counterpoint adalah suatu cara dalam proses pembelajaran yang memberikan kesempatan kepada siswa untuk aktif berargumen (mengajukan ideide, gagasan-gagasan) dari persoalanpersoalan yang muncul atau sengaja dimunculkan dalam pembelajaran sesuai dengan aturan-aturan yang telah ada (Dewi Wulandari, 2012)

Mel Silberman (2009: mengatakan bahwa strategi ini merupakan sebuah teknik hebat untuk merangsang diskusi dan mendapatkan pemahaman lebih mendalam tentang berbagai isu yang kompleks. Format tersebut mirip dengan sebuah perdebatan, namun tidak terlalu formal dan berjalan dengan lebih cepat. Strategi ini sangat baik dipakai untuk melibatkan siswa dalam mendiskusikan isuisu kompleks secara mendalam. Strategi ini dapat diterapkan jika guru hendak menyajikan topik atau permasalahan yang menimbulkan berbagai pandangan yang berbeda. (Marno \& M. Idris, 2008: 180)

Dari pendapat-pendapat $\mathrm{d}$ iatas dapat dikatakan bahwa strategi Point Counterpoint merupakan strategi yang mengasah argumen, ide-ide dan gagasangagasan siswa untuk menyelesaikan permasalahan yang menimbulkan perbedaan pandangan/pemikiran dengan cara mendiskusikannya dengan temanteman yang lain.

Kelebihan dan Kekurangan Strategi Point Counterpoint
1. Kelebihan Strategi Pembelajaran Point Counterpoint

a. Dengan diskusi akan mempertajam hasil pembicaraan.

b. Siswa dapat terangsang untuk menganalisa masalah di dalam kelompok, asal terpimpin sehingga analisa itu terarah pada pokok permasalahan yang dikehendaki bersama.

c. Dalam pertemuan debat itu siswa dapat menyampaikan fakta dari kedua sisi masalah; kemudian di teliti fakta mana yang benar/valid dan bisa di pertanggung jawabkan bersama dalam satu kelompok.

d. Karena terjadi pembicaraan aktif antar kelompok maka akan membangkitkan daya tarik para siswa untuk turut berbicara, turut berpartisipasi untuk mengeluarkan pendapat.

e. apabila permasalahan yang didiskusikan menarik, maka pembicaraan itu mampu mempertahankan minat anak untuk terus mengikuti pendapat itu.

f. strategi ini dapat di gunakan pada kelompok yang besar.

2. Kekurangan Strategi Pembelajaran Point Counterpoint

a. Dalam diskusi ini kadang-kadang keinginan untuk menang mungkin terlalu besar, sehingga tidak memperhatikan pendapat orang lain.

b. Kemungkinan lain di antara anggota mendapat kesan yang salah tentang orang yang berdebat. 
c. Karena hebatnya perdebatan bisa terjadi terlalu banyak emosi yang terlibat, sehingga debat itu semakin ramai.

d. Agar bisa melaksanakan dengan baik maka perlu persiapan yang teliti dan matang sebelumnya (Roestijah, 2008)

\section{Hasil Belajar Mata Pelajaran Fiqh}

Menurut Purwanto (2008: 34) hasil belajar merupakan perubahan perilaku siswa akibat belajar yang diupayakan dari adanya proses belajar mengajar untuk mencapai tujuan pendidikan. Sedangkan menurut Nana Sudjana (2005: 22) bahwa hasil belajar adalah kemampuankemampuan yang dimiliki siswa setelah ia menerima pengalaman belajarnya.

Hasil belajar adalah kemampuan yang didapat anak setelah melalui kegiatan belajar. Belajar itu sendiri merupakan proses dari seseorang yang berusaha untuk memperoleh suatu bentuk perubahan perilaku yang relatif menetap. Dalam kegiatan pembelajaran, biasanya guru menetapkan tujuan belajar. Siswa yang berhasil dalam belajar adalah yang berhasil mencapai tujuan-tujuan pembelajaran (Asep Jihad dan Abdul Haris, 2008: 14)

Dari pengertian diatas dapat dikatakan bahwa hasil belajar adalah perubahan-perubahan yang terjadi pada individu siswa akibat adanya pengalaman baru dalam proses pembelajaran yang sesuai dengan tujuan-tujuan yang telah ditentukan.

Setelah siswa mengalami serangkaian proses pembelajaran, maka untuk mengetahui apakah proses pembelajaran tersebut berhasil atau belum dalam mencapai tujuan pembelajaran, diperlukan suatu bentuk penilaian pembelajaran. Menurut Nana Sudjana (2004: 22) penilaian hasil belajar adalah proses pemberian nilai terhadap hasil-hasil belajar yang dicapai siswa dengan kriteria tertentu, sehingga hasil belajar merupakan objek dari suatu penilaian.

Mata pelajaran adalah satuan atau sekumpulan bahan kajian yang diajarkan kepada siswa untuk mencapai tujuan pendidikan. Mata pelajaran tersebut tersebar disemua tingkat, dan semua tingkat memiliki kedalaman yang berbeda sesuai dengan perkembangan psikologi siswa (H.M Arifin: 182). Sedangkan fiqh adalah ilmu tentang hukum-hukum syar'i yang bersifat amaliyah yang digali dan ditemukan dari dalil-dalil tafsili (Amir Syaifuddin, 2008: 3)

Dengan demikian, mata pelajaran fiqh dapat dirtikan sebagai satuan/sekumpulan bahan kajian yang berisi tentang ilmu-ilmu hukum syar'i yang diajarkan kepada siswa untuk mencapai tujuan pendidikan. Lain halnya dengan Depag (2007: 24) mengatakan mata pelajaran fiqh adalah salah satu mata pelajaran yang membahas ajaran agama Islam dari segi syariat Islam tentang caracara manusia melaksanakan ibadah kepada Allah dan mengatur kehidupannya

Dari berbagai pengertian diatas dapat dikatakan bahwa mata pelajaran fiqh adalah sekumpulan bahan ajar agama Islam yang lebih menekankan pada aspek bagaimana siswa mampu melaksanakan 
Pengaruh Strategi Pembelajaran Point Counterpoint

Terhadap Hasil Belajar Mata Pelajaran Figh Siswa

MAN Karanggede Tahun 2014/2015

ibadah dan muamalah dengan baik dan benar sesuai dengan hukum syar'i atau syariat Islam. Dalam penelitian ini adalah mata pelajaran fiqh kelas XI tingkat Madrasah Aliyah ysng memiliki beberapa ruang lingkup, yaitu:

1. Ketentuan Islam tentang jinayah

2. Ketentuan Islam tentang peradilan

3. Ketentuan Islam tentang keluarga

4. Ketentuan Islam tentang mawaris

5. Ketentuan Islam tentang hudud

\section{METODE PENELITIAN}

penelitian ini menggunakan metode eksperimen. Dalam metode eksperimen peneliti dengan sengaja dan secara sistematis mangadakan perlakuan variabel (manipulasi) dalam peristiwa alamiah, kemudian mengamati konsekuensi dari perlakuan tersebut. (Nana Sudjana, 2001: 19). Dengan kata lain eksperimen adalah suatu cara untuk mencari pengaruh atau perbedaan antara dua strategi pembelajaran yang sengaja dilakukan peneliti untuk mengetahui akibat dari perlakuan tersebut. Desain dalam penelitian ini menggunakan Static Group Comparison (Suharsimi Arikunto, 2006: 86) dengan pola:

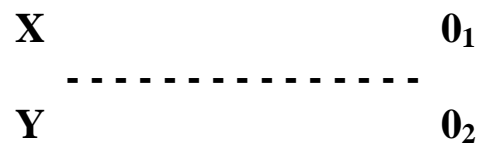

Keterangan: $\mathbf{X}$ : Ada treatment

(perlakuan)

Y : Tidak ada treatment (perlakuan)

01 : Hasil belajar siswa kelas XI yang diajar dengan strategi Point Counterpoint yang disebut kelompok eksperimen $\mathbf{0}_{2}$ : Hasil belajar siswa kelas XI yang diajarkan dengan metode konvensional yang disebut kelompok kontrol

Proses Penelitian ini bersifat deduktif, dimana untuk menjawab rumusan masalah digunakan konsep atau teori, sehingga dapat dirumuskan hipotesis. Hipotesis tersebut selanjutnya akan di uji melalui pengumpulan data di lapangan. Untuk pengumpulan data tersebut, digunakan instrumen penelitian. Data yang terkumpul selanjutnya akan di analisis secara kuantitatif dengan menggunakan statistik deskriftif sehingga dapat disimpulkan hipotesis yang dirumuskan akan dapat terbukti atau tidak.

\section{Teknik Pengumpulan Data}

Teknik pengumpulan data dalam penelitian yang penulis lakukan ini adalah:

1. Tes

Tes merupakan salah satu cara pengumpulan data yang menghadapkan sejumlah pertanyaan yang bersifat mengukur (Nana Syaodih Sukamadinata, 2010: 245). Pada penelitian ini metode tes digunakan untuk mengumpulkan data mengenai hasil belajar mata pelajaran fiqh siswa yang pembelajarannya menggunakan metode konvensional dan siswa yang pembelajarannya menggunakan strategi pembelajaran Point Counterpoint. Hal ini ditempuh untuk mengukur pengetahuan, dan pemahaman siswa pada mata pelajaran fiqh. Tes yang diberikan kepada siswa berbentuk pilihan ganda sebanyak 30 butir soal. 
2. Dokumentasi

Dokumentasi adalah suatu teknik pengumpulan data yang menghimpun data dan menganalisis dokumendokumen, baik dokumen tertulis, gambar ataupun elektronik (Nana Syaodih Sukamadinata, 2010: 221). Dalam hal ini metode dokumentasi digunakan untuk untuk mendapatkan sumber dokumen jumlah siswa dan nama-nama sampel.

\section{Instrumen Penelitian}

1. Definisi Konseptual

Proses belajar merupakan serangkaian proses pembelajaran aktif melalui latihan dan pengalaman sehingga menghasilkan berbagai perubahan positif. Perubahan tersebut meliputi mental dan fisik yang terintegrasi pada ranah kognitif, afektif, dan psikomotorik. Perubahan akibat dari proses belajar disebut hasil belajar. Hasil belajar pada mata pelajaran fiqh merupakan perubahan kemampuan siswa secara kognitif, afektif, dan psikomotorik dalam mengaplikasikan apa yang telah didapat. Tidak hanya secara teori, namun siswa mampu menerapkannya dalam kehidupan nyata.

2. Definisi Operasional

Hasil belajar pada mata pelajaran fiqh merupakan perubahan kemampuan siswa meliputi aspek kognitif, afektif, dan psikomotorik dalam mengaplikasikan pemahaman yang telah didapat dari pembelajaran tersebut. Dalam penelitian ini, aspek yang akan diukur peneliti adalah aspek kognitif berupa hasil belajar mata pelajaran fiqh pada pokok bahasan hudud. Materi ini terdiri dari beberapa sub bahasan yaitu tentang zina, tentang qadzaf dan tentang minuman keras. Dari ketiga sub bahasan ini dibuat bentuk-bentuk soal objektif pilihan ganda (multiple choice) sebanyak 30 soal dengan 4 pilihan jawaban yaitu a, b, c dan d.

3. Kisi-Kisi Instrumen

Sebelum dilakukan penyusunan test, terlebih dahulu dibuat alat ukur yang sesuai dengan tujuan penelitian yang dilakukan yang berupa kisi-kisi tes. Soal test yang diberikan berjumlah 30 dengan bentuk pilihan ganda yang terdiri dari empat pilihan jawaban yaitu a, b, c, d.

4. Uji Coba Instrumen

a. Uji Validitas

Uji validitas adalah suatu ukuran yang menunjukan tingkat kevalidan atau keshahihan suatu instrumen (Suharsimi Arikunto, 2006: 168). Dalam penelitian ini uji validitas digunakan untuk menguji tes tingkat pemahaman siswa dengan metode korelasi butir total. Teknik yang digunakan adalah korelasi product moment dengan rumus sebagai berikut:

$$
\begin{aligned}
& r_{x y}=\frac{\mathrm{N} \sum \mathrm{XY}-\left(\sum \mathrm{X}\right)\left(\sum \mathrm{Y}\right)}{\sqrt{\left\{\mathrm{N} \sum \mathrm{X}^{2}-\left(\sum \mathrm{X}^{2}\right)\right\}\left\{\mathrm{N} \sum \mathrm{Y}^{2}-\left(\sum \mathrm{Y}^{2}\right)\right\}}} \\
& \mathrm{r}_{\mathrm{xy}}=\text { Koefisien Korelasi } \\
& \text { (Validitas) } \\
& \mathrm{N}=\text { Jumlah Responden } \\
& \mathrm{X}=\text { Skor Item } \\
& \mathrm{Y}=\text { Skor Total }
\end{aligned}
$$


Keputusan ujinya adalah jika rxy $>$ rtabel pada taraf signifikan 5\% berarti butir soal dinyatakan valid dan sebaliknya jika rxy < rtabel pada taraf signifikan 5\% maka butir soal dinyatakan tidak valid (Suharsimi Arikunto, 2006: 143)

Uji coba instrumen dalam penelitian ini dilaksanakan di MAN Karanggede kelas XI IPA 2 yang berjumlah 25 siswa. Dari 35 butir soal yang diujicobakan terdapat 31 soal valid dan 4 butir soal tidak valid. Dari butir soal yang valid diperoleh validitas tertinggi adalah 0.722 dan validitas terrendah adalah 0,399. (Lampiran 3)

b. Reliabilitas

Uji reliabilitas adalah keterpercayaan yang berhub dengan ketetapan dan konsistensi. Menurut Purwanto (2007: 161) suatu alat ukur dinyatakan reliabilitas apabila alat

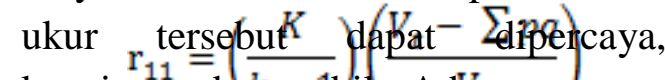
konsisten dalk stabil Adlapun numus yang digunakan untuk menguji reliabilitas instrumen dengan menggunakan Kuder-Richartdson (KR-20) sebagai berikut:

\begin{tabular}{|c|c|}
\hline $\begin{array}{c}\mathrm{r}_{11} \\
\text { (Reliabilitas) }\end{array}$ & $=$ Koefisisen Korelasi \\
\hline $\mathrm{K}$ & $=$ Jumlah Butir \\
\hline $\mathrm{V}_{\mathrm{t}}$ & $=$ Varians Total \\
\hline $\mathrm{P}$ & $=$ Proporsi Skor yang \\
\hline Didap & \\
\hline
\end{tabular}

$$
\begin{array}{lcc}
\mathrm{q} \quad & \text { Proporsi } & \text { Skor } \\
\text { Maksimum } & \text { Dikurangi } & \text { Skor } \\
\text { yang Didapat } & &
\end{array}
$$

Kriteria uji penelitian ini jika $\mathrm{r}_{\text {hitung }}>\mathrm{r}_{\text {tabel }}$ maka instrumen dinyatakan reliabel dan sebaliknya jika $r_{\text {hitung }}<r_{\text {tabel }}$ maka instrumen dinyatakan tidak reliabel (Suharsimi Arikunto, 2006: 188)

Dari hasil uji coba instrumen yang dilakukan didapatkan $r_{\text {hitung }}$ sebesar 0,91 yang dengan $\mathrm{N} 25$ dan taraf signifikasi $5 \%$ didapat $r_{\text {tabel }}$ sebesar 0,396. Ini menunjukkan bahwa $r_{\text {hitung }}(0,91)>r_{\text {tabel }}(0,396)$ sehingga instrumen dinyatakan reliabel.

\section{Teknik Analisis Data}

1. Teknik Analisis Unit

Menurut Suharyadi (2003: 55) dalam perhitungan analisis deskriptif terdiri dari:

\section{a. Mean/Rataan}

Mean adalah teknik penjelasan kelompok yang didasarkan atas nilai rata-rata kelompok tersebut (Sugiyono, 2007: 49)

$$
M e=\frac{\sum f_{i x i}}{n}
$$

Dimana: Me : Rata-rata hitung data berkelompok

$$
\begin{aligned}
& \sum \quad \text { : Total } \\
& \text { operasi penjumlahan (epsilon) } \\
& \mathrm{f}_{\mathrm{i}} \quad \text { : Frekuensi ke } \\
& \text { i sampai ke } \mathrm{n} \\
& \mathrm{x}_{\mathrm{i}} \quad \text { : Nilai } \mathrm{x} \text { ke } \mathrm{i} \\
& \text { sampai ke } n
\end{aligned}
$$




\section{n : Jumlah total \\ responden}

b. Median/Nilai Tengah

Median adalah salah satu teknik penjelasan kelompok yang didasrkan atas nilai tengah dari kelompok data yang telah disusun urutannya daari yang terkecil sampai yang terbesar (Sugiyono, 2007: 48)

$$
M d=\mathrm{b}+p\left(\frac{1 / 2^{\mathrm{n}}-\mathrm{F}}{\mathrm{f}}\right)
$$

Dimana: Md :

Nilai

Median

b : Batas bawah

atau tepi kelas dimana median

berada

$\mathrm{p} \quad$ : Panjang

n : Banyaknya

data / jumlah sampel

F : jumlah

frekuensi sebelum kelas median

f : Frekuensi

kelas median

c. Modus

Modus merupakan teknik penjelaasan kelompok yang didasrkan atas nilai yang sedang populer (yang sedang menjadi mode) atau nilai yang sering muncul dalam kelompok tersebut (Sugiyono, 2007: 47)

$$
\text { Mo }=b+p\left(\frac{\mathrm{b}_{1}}{\mathrm{~b}_{1}+\mathrm{b}_{2}}\right)
$$

Dimana: Mo : Nilai Modus b : Batas bawah atau tepi kelas dimana modus berada

$$
\mathrm{d}_{1} \quad \text { : Selisih }
$$

frekuensi kelas modus dengan kelas sebelumnya $\mathrm{d}_{2} \quad$ : Selisih

frekuensi kelas modus dengan kelas sesudahnya

kelas interval

$$
\text { p : : Panjang }
$$

d. Standar Deviasi

$$
S=\sqrt{\frac{\sum f i x i^{2}-\frac{(f i x i)^{2}}{n}}{n-1}}
$$

Dimana $\sum$ : Total operasi penjumlahan (epsilon)

Nilai x ke i sampai ke $n$

$$
\mathrm{f}_{\mathrm{i}} \quad \text { : Frekuensi ke i sampai }
$$

ke $\mathrm{n} \quad \mathrm{n}$ : Jumlah total responden

2. Uji Prasyarat Analisis Statistik

Setelah data didapat dari penjelasaan penelitian yang dilakukan selanjutnya adalah pengujian terhadap data tersebut. Adapun pengujian data adalah sebagai berikut:

a. Uji Normalitas

Untuk menguji data yang diperoleh berdistribusi normal atau tidak maka dilakukan uji normalitas. Dalam penelitian ini rumus uji normalitas yang digunakan adalah chi kuadrat sebagai berikut:

$$
\chi^{2}=\sum \frac{(\mathrm{fo}-\mathrm{fh})^{2}}{\mathrm{fh}}
$$

Keterangan $: \chi^{2}:$ chi kuadrat 


$$
\begin{array}{ll}
\text { yang didapatkan } & \text { fo frekuensi } \\
\text { yang diharapkan } & \text { fh : frekuensi }
\end{array}
$$

Hasil perhitungan $\chi^{2}$ hitung dicocokkan dengan tabel chi kuadrat, jika $\chi_{\text {hitung }}^{2}<\chi_{\text {tabel maka dapat }}^{2}$ dikatakan distribusi data normal dan sebaliknya apabila $\chi_{\text {hitung }}^{2}>\chi_{\text {tabel }}^{2}$ maka distribusi data tidak normal (Sugiyono, 2007: 107-109)

\section{b. Uji Homogenitas}

Untuk menguji varian kedua sampel homogen atau tidak maka pengujian pomogrian terbesar digunakan uji $\mathrm{F}$

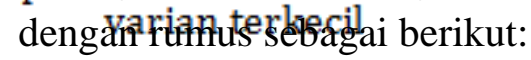

Dimana F adalah nilai yang dicari , varian adalah kuadrat dari simpangan baku

Dalam hal ini berlaku ketentuan, bila harga Fhitung < dengan Ftabel maka data dikatakan homogen dan sebaliknya jika Fhitung > dengan Ftabel maka data tidak homogen (Sugiyono, 2007: 175)

c. Uji Keseimbangan

Sebelum eksperimen berlangsung, kelompok eksperimen dan kelompok kontrol yang merupakan sampel penelitian terlebih dahulu di uji keseimbangan kemampuan awalnya. Dalam penelitian ini data nilai ulangan mata pelajaran fiqh digunakan untuk menguji keseimbangan rata-rata kemampuan awalnya. Hal ini dimaksudkan agar hasil dari eksperimen benar-benar akibat dari perlakuan yang dibuat, bukan pengaruh yang lain. Keseimbangan rata-rata kedua kelompok sampel di uji dengan uji-t dengan rumus:

1) Hipotesis

$$
\text { Ho : } \mu_{1}=\mu_{2}
$$

Ho : $\mu 1 \neq \mu 2$

2) Tingkat Signifikan : $\alpha=0,05$

3) Statistik Uji

$$
t=\frac{\bar{x}_{1}-\bar{x}_{2}}{\sqrt{\frac{s_{1}^{2}}{n_{1}}+\frac{s_{2}^{2}}{n_{2}}}}
$$

Dimana:

$\begin{array}{lrrrr} & : & \text { Nilai } & \mathrm{t} & \text { yang } \\ \text { dihitung } & \mathrm{s} 2 & & : & \\ \text { Varian } & & & \end{array}$

$$
\overline{\mathrm{x}} \quad: \text { Rata }-\operatorname{rata} \mathrm{x}
$$

Jumlah anggota sampel

4) Keputusan Uji

Jika thitung $\leq$ tabel maka Ho diterima dan Ha ditolak

Jika thitung > ttabel maka Ho ditolak dan Ha diterima

(Sugiyono, 2007: 132)

\section{Analisis Hipotesis}

Dalam penelitian eksperimen ini, teknik analisis kerja dapat disebut indikator kerja. Penelitian ini dapat disimpulkan jika hasil penelitian telah dikonsultasikan dengan tabel t-tes. T-tes adalah tes statistic yang dipakai untuk menguji perbedaan/persamaan dua kondisi/ perlakuan atau dua kelompok yang berbeda dengan prinsip 
perbandingan rata-rata (mean) kedua kelompok atau perlakuan itu (Subana dan Moersetyo Rahadi, 2005: 168). Rumus t-tes yang digunakan dalam penelitian ini adalah sebagai berikut:

$$
t=\frac{\bar{x}_{1}-\bar{x}_{2}}{\sqrt{\frac{s_{1}^{2}}{n_{1}}+\frac{s_{2}^{2}}{n_{2}}-2 r\left(\frac{s_{1}}{\sqrt{n_{1}}}\right)\left(\frac{s_{2}}{\sqrt{n_{2}}}\right)}}
$$

Dimana:

$$
\begin{aligned}
& \mathrm{x}_{1} \text { : Rata-rata sampel } 1 \quad \mathrm{~s}_{1}^{2} \text { : Varian } \\
& \text { sampel } 1 \\
& \mathrm{x}_{2} \text { : Rata-rata sampel } 2 \quad \mathrm{~s}_{1}^{2}: \quad \text { Varian } \\
& \text { sampel } 2 \\
& \mathrm{n}_{1} \text { : Jumlah sampel 1 } \\
& \quad \mathrm{r}: \text { Korelasi kedua sampel } \\
& \mathrm{n}_{2}: \text { Jumlah sampel } 2
\end{aligned}
$$

\section{Kriteria uji}

Jika $t_{\text {hitung }}>t_{\text {tabel }}$ maka Ha diterima dan Ho ditolak, dan sebaliknya jika $t_{\text {hitung }}<t_{\text {tabel }}$ maka Ha ditolak dan Ho diterima (Sugiyono, 2007: 122)

\section{Hasil Penelitian dan Pembahasan Deskripsi Penelitian}

Penelitian yang dilakukan terhadap siswa kelas XI IPA 1, XI IPA 5, XI IPS 1 dan XI IPS 2 siswa MAN Karanggede dikelompokkan rnenjadi 2 kelas yaitu kelas XI IPA 1 dan XI IPS 2 sebagai kelas ekperimen dan kelas XI IPA 5 dan XI IPS 1 sebagai kelas kontrol. Kelompok kelas kontrol memperoleh pembelajaran dengan metode konvensional sedangkan kelompok eksperimen menggunakan strategi pembelajaran Point Counterpoint. Pertemuan pembelajaran dilakukan sebanyak 4 kali dalam waktu 1 bulan baik kelas kontrol maupun kelas eksperimen. Tiap pertemuan selama 40 menit untuk 2 jam pertemuan ( 2 x 40 menit). Pertemuan pembelajaran kelas kontrol dilaksanakan pada hari Kamis jam ke 3-4 (XI IPS 1) dan jam ke 5-6 (XI IPA 5). Sedangkan untuk kelas eksperimen dilaksanakan pada hari Selasa jam ke 5-6 (XI IPS 2) dan Sabtu jam ke 3-4 (XI IPA 1). Pertemuan ke-1 kelas eksperimen maupun kelas kontrol dengan materi hudud berkaitan dengan sub bab zina, pertemuan ke-2 dengan materi qadzaf, pertemuan ke-3 dengan materi minuman keras dan pertemuan ke-4 diadakan postest.

Proses pembelajaran pada kelompok kontrol pada awal pembelajaran siswa tenang, konsentrasi untuk mendengarkan dan mengikuti proses pembelajaran dengan baik. Setelah itu siswa mulai merasakan bosan dan jenuh yang terbukti dengan adanya tingkah laku para siswa yang rame sendiri dan bermain HP, bahkan ada beberapa siswa yang ngantuk serta kepalanya ditaruh di atas meja. Hal ini dikarenakan siswa hanya sebagai pendengar dan pengikut pikiran guru saja, tidak aktif dalam pembelajaran karena didominasi oleh guru. Hal ini terus berulang sampai pertemuan ketiga saat peneliti melakukan pembelajaran yang terakhir.

Kelompok kedua sebagai kelornpok ekspeimen, para siswa yang berada dalam kelas eksperimen terbagi dalam kelompokkelompok kecil, yang terdiri dari 5-6 siswa. Kelompok ini dikenai perlakuan dengan menggunakan strategi pembelajaran Point Counterpoint. Siswa nampaknya sangat gaduh saat pertama kali peneliti meminta para siswa untuk mengelompok dan duduk 
sesuai kelompok masing-masing, bahkan ada beberapa siswa yang mereka mencoba tidak mau mengelompok dengan alasan guru-guru tidak pernah melakukan hal seperti itu sehingga mereka merasa nyaman dengan posisinya sebagai siswa yang pasif. Namun setelah teman yang lain selesai berkelompok-kelompok dan mendapat sedikit penjelasan dari peneliti akhirnya mereka mau ikut membentuk kelompok. Dan setelah pembelajaran selesai banyak siswa yang memberikan kesan bahwa pembelajarannya menyenangkan dan mereka bisa saling bertukar pikiran dengan argumen yang mereka miliki.

\section{Deskripsi Data}

Deskripsi Data Hasil Belajar Mata Pelajaran Fiqh pada Kelas yang Menggunakan Metode Konvensional (Kelas Kontrol)

Berdasarkan hasil tes, didapatkan skor tertinggi 24, skor terendah 7, dan rentang (range) sebesar 17. Dari perhitungan yang dilakukan terhadap hasil tes didapatkan mean 14,60, median 14,28, modus 13,88 dan standar deviasi 3,71. Data ini memiliki skala 1:3,33 sehingga setiap satu nilai mewakili nilai 3,33.

Distribusi frekuensi data hasil belajar mata pelajaran fiqh pada siswa kelas XI di MAN Karanggede adalah sebagai berikut:

$\begin{array}{lllll}\text { Maksimal } & : 24 & \text { Kelas } & : 6 & \text { Range }: 17 \\ \text { Minimal } & : 7 & \text { Panjang kelas }: 3 & \end{array}$

Tabel 1

Distribusi Frekuensi Data Hasil Belajar Kelas yang Menggunakan Metode Konvensional (Kelas Kontrol)

\begin{tabular}{|c|c|c|c|c|}
\hline Interval & Frekuensi & Frek-relt & Frek-Kum & Frek-kum-relt \\
\hline $7-9$ & 3 & $6,67 \%$ & 3 & $6,67 \%$ \\
\hline $10-12$ & 10 & $22,22 \%$ & 13 & $28,89 \%$ \\
\hline $\mathbf{1 3}-\mathbf{1 5}$ & $\mathbf{1 6}$ & $\mathbf{3 5 , 5 6 \%}$ & $\mathbf{2 9}$ & $\mathbf{6 4 , 4 4 \%}$ \\
\hline $16-18$ & 9 & $20,00 \%$ & 38 & $84,44 \%$ \\
\hline $19-21$ & 5 & $11,11 \%$ & 43 & $95,56 \%$ \\
\hline $22-24$ & 2 & $4,44 \%$ & 45 & $100,00 \%$ \\
\hline Jumlah & $\mathbf{4 5}$ & $\mathbf{1 0 0 , 0 0 \%}$ & & \\
\hline
\end{tabular}

Dari distribusi frekuensi tersebut nilai rata-rata dan median terletak antara interval 13-15 yang memiliki frekuensi sebanyak 16 atau frekuensi relatif 35,56\%. Kedekatan mean dan median menunjukkan bahwa data sangat baik untuk menjadi alat ukur populasi. 
Tabel 2

Tingkat Katagori Data Hasil Belajar Kelas yang Menggunakan Metode Konvensional (Kelas Kontrol)

\begin{tabular}{|c|c|c|c|c|}
\hline Interval & Frekuensi & Persentase & Katagori & Persentase-kum \\
\hline $7-9$ & 3 & $6,67 \%$ & Rendah & \multirow{2}{*}{$28,89 \%$} \\
\hline $10-12$ & 10 & $22,22 \%$ & Rendah & \\
\hline $13-15$ & 16 & $35,56 \%$ & Sedang & \multirow{2}{*}{$55,56 \%$} \\
\hline $16-18$ & 9 & $20,00 \%$ & Sedang & \\
\hline $19-21$ & 5 & $11,11 \%$ & Tinggi & \multirow{2}{*}{$15,56 \%$} \\
\hline $22-24$ & 2 & $4,44 \%$ & Tinggi & \\
\hline Jumlah & 45 & $100,00 \%$ & & $100,00 \%$ \\
\hline
\end{tabular}

Berdasarkan tabel diatas siswa yang memperoleh nilai dalam katagori tinggi terletak pada interval 19-24 yang mencapai tingkat persentase $15,56 \%$, siswa dengan katagori sedang terletak pada interval 13-18 dengan tingkat persentase $55,56 \%$ dan siswa dengan katagori rendah terletak pada interval 7-12 dengan tingkat persentase $28,89 \%$. Sehingga dari hasil penelitian tersebut siswa yang dalam pembelajarannya tidak menggunakan strategi pembelajaran Point Counterpoint (mengunakan metode konvensional) persentase terbanyak dicapai pada katagori tingkat sedang yaitu pada interval 13-18.

Maksimal : 28

Minimal $: 6$
Deskripsi Data Hasil Belajar Mata Pelajaran Fiqh pada Kelas yang Menggunakan Strategi Pembelajaran Point Counterpoint (Kelas Eksperimen)

Berdasarkan hasil tes, didapatkan skor tertinggi 28 , skor terendah 6 , dan rentang (range) sebesar 22. Dari perhitungan yang dilakukan terhadap hasil tes didapatkan mean 18,61, median 19,03, modus 19,63 dan standar deviasi 4,58. Data ini memiliki skala 1:3,33 sehingga setiap satu nilai mewakili nilai 3,33.

Distribusi frekuensi data hasil belajar mata pelajaran fiqh pada siswa kelas XI di MAN Karanggede adalah sebagai berikut: 
Tabel 3

Distribusi Frekuensi Data Hasil Belajar Kelas yang Menggunakan Strategi Pembelajaran Point Counterpoint (Kelas Eksperimen)

\begin{tabular}{|c|c|c|c|c|}
\hline Interval & Frekuensi & Frek-relt & Frek-Kum & Frek-kum-relt \\
\hline $6-9$ & 1 & $2.22 \%$ & 1 & $2.22 \%$ \\
\hline $10-13$ & 6 & $13.33 \%$ & 7 & $15.56 \%$ \\
\hline $14-17$ & 9 & $20.00 \%$ & 16 & $35.56 \%$ \\
\hline $\mathbf{1 8}-\mathbf{2 1}$ & $\mathbf{1 7}$ & $\mathbf{3 7 . 7 8 \%}$ & $\mathbf{3 3}$ & $\mathbf{7 3 . 3 3 \%}$ \\
\hline $22-25$ & 10 & $22.22 \%$ & 43 & $95.56 \%$ \\
\hline $26-29$ & 2 & $4.44 \%$ & 45 & $100.00 \%$ \\
\hline Jumlah & $\mathbf{4 5}$ & $\mathbf{1 0 0 . 0 0 \%}$ & & \\
\hline
\end{tabular}

Dari distribusi frekuensi tersebut nilai rata-rata dan median terletak antara interval 18-21 yang memiliki frekuensi sebanyak 17 atau frekuensi relatif $37,78 \%$. Kedekatan mean dan median menunjukkan bahwa data sangat baik untuk menjadi alat

Tabel 4 ukur populasi. Adapun tingkat katagori data hasil belajar mata pelajaran fiqh yang menggunakan Strategi Pembelajaran Point Counterpoint (kelas eksperimen) adalah sebagai berikut:

Tingkat Katagori Data Hasil Belajar Kelas yang Menggunakan Strategi

Pembelajaran Point Counterpoint (Kelas Eksperimen)

\begin{tabular}{|c|c|c|c|c|}
\hline Interval & Frekuensi & Persentase & Katagori & Persentase-kum \\
\hline $6-9$ & 1 & $2.22 \%$ & Rendah & \multirow{2}{*}{$15.56 \%$} \\
\hline $10-13$ & 6 & $13.33 \%$ & Rendah & \\
\hline $14-17$ & 9 & $20.00 \%$ & Sedang & \multirow{2}{*}{$57.78 \%$} \\
\hline $18-21$ & 17 & $37.78 \%$ & Sedang & \\
\hline $22-25$ & 10 & $22.22 \%$ & Tinggi & \multirow{2}{*}{$26.67 \%$} \\
\hline $26-29$ & 2 & $4.44 \%$ & Tinggi & \\
\hline Jumlah & $\mathbf{4 5}$ & $\mathbf{1 0 0 . 0 0 \%}$ & & $\mathbf{1 0 0 . 0 0 \%}$ \\
\hline
\end{tabular}

Berdasarkan tabel diatas siswa yang memperoleh nilai dalam katagori tinggi terletak pada interval 22-29 yang mencapai tingkat persentase $26,67 \%$, siswa dengan katagori sedang terletak pada interval 14-21 dengan tingkat persentase $57,78 \%$ dan siswa dengan katagori rendah terletak pada interval 6-13 dengan tingkat persentase $15,56 \%$. Sehingga dari hasil tersebut siswa yang pembelajarannya menggunakan strategi pembelajaran Point Counterpoint persentase terbanyak dicapai pada katagori sedang yaitu pada interval 14-21.

Adapun diagram persentase hasil belajar mata pelajaran fiqh yang menggunakan Strategi Pembelajaran Point Counterpoint (kelas eksperimen) adalah sebagai berikut: 


\section{Teknik Analisis Data}

\section{Pengujian Prasyarat}

\section{a. Uji Normalitas}

1) Uji Normalitas Hasil Belajar Mata Pelajaran Fiqh pada Kelas yang Menggunakan Metode

Konfensional (Kelas Kontrol)

Statistik penguji menggunakan

uji chi kuadrat dengan rumus:

$$
\chi^{2}=\sum \frac{(\mathrm{fo}-\mathrm{fh})^{2}}{\mathrm{fh}}
$$

fo : frekuensi yang

didapatkan

fh : frekuensi yang

diharapkan (persentase luas bidang kali n)

Dimana:

Tabel 5

Tabel Penolong Untuk Pengujian Normalitas Data Dengan Chi Kuadrat $\left(\chi^{2}\right)$

\begin{tabular}{|c|c|c|c|c|c|}
\hline Interval & $\boldsymbol{F o}$ & $\boldsymbol{F h}$ & $\boldsymbol{f o - f h}$ & $(\boldsymbol{f o - f h})^{\mathbf{2}}$ & $(\boldsymbol{f o - f h})^{\mathbf{2}} / \boldsymbol{f h}$ \\
\hline $7-9$ & 3 & 1 & 2 & 4 & 4 \\
\hline $10-12$ & 10 & 6 & 4 & 16 & 2,67 \\
\hline $13-15$ & 16 & 15 & 1 & 1 & 0,07 \\
\hline $16-18$ & 9 & 15 & -6 & 36 & 2,4 \\
\hline $19-21$ & 5 & 6 & -1 & 1 & 0,17 \\
\hline $22-24$ & 2 & 1 & 1 & 1 & 1 \\
\hline Jumlah & $\mathbf{4 5}$ & & & & $\mathbf{1 0 , 3 1}$ \\
\hline
\end{tabular}

Cara menghitung $f h$ :

a) Baris pertama 2,7\% $\times 45=1,22$ (dibulatkan menjadi 1)

b) Baris kedua $13,53 \%$ x 45=6,09 (dibulatkan menjadi 6)

c) Baris ketiga $34,13 \%$ x 45=15,36 (dibulatkan menjadi 15)

d) Baris keempat 34,13\% x 45=15,36 (dibulatkan menjadi 15)

e) Baris kelima 13,53\% x 45=6,09 (dibulatkan menjadi 6)

f) Baris keenam 2,7\% x 45=1,22 (dibulatkan menjadi 1)

Dari perhitungan chi kuadrat tersebut diperoleh nilai 10,31. Kemudian dikonsultasikan dengan chi kuadrat tabel $\left(\chi_{\text {tabel }}^{2}\right)$ pada $\mathrm{db}$ 6-1 pada taraf signifikansi $5 \%$ diperoleh
11,070. Karena harga $\chi_{\text {hitung }}^{2}$ $(10,31)<\chi_{\text {tabel }}^{2}(11.070)$ maka data hasil belajar mata pelajaran fiqh yang menggunakan metode konfensional (kelas kontrol) berdistribusi normal. 
2) Uji Normalitas Hasil Belajar Mata Pelajaran Fiqh pada Kelas yang Menggunakan Strategi Pembelajaran Point Counterpoint (Kelas

Eksperimen)
Statistik penguji

menggunakan uji chi

kuadrat dengan rumus:

$$
\chi^{2}=\sum \frac{(\mathrm{fo}-\mathrm{fh})^{2}}{\mathrm{fh}}
$$

Dimana:

fo : frekuensi yang didaparkan

fh : frekuensi yang diharapkan (persentase luas bidang kali n)

Tabel 6

Tabel Penolong Untuk Pengujian Normalitas Data Dengan Chi Kuadrat $\left(\chi^{2}\right)$

\begin{tabular}{|c|c|c|c|c|c|}
\hline Interval & $\boldsymbol{F o}$ & $\boldsymbol{F h}$ & $\boldsymbol{f o}-\boldsymbol{f h}$ & $(\boldsymbol{f o}-\boldsymbol{f h})^{\mathbf{2}}$ & $(\boldsymbol{f o - f h})^{\mathbf{2}} / \boldsymbol{f h}$ \\
\hline $6-9$ & 1 & 1 & 0 & 0 & 0 \\
\hline $10-13$ & 6 & 6 & 0 & 0 & 0 \\
\hline $14-17$ & 9 & 15 & -6 & 36 & 2.4 \\
\hline $18-21$ & 17 & 15 & 2 & 4 & 0.27 \\
\hline $22-25$ & 10 & 6 & 4 & 16 & 2.67 \\
\hline $26-29$ & 2 & 1 & 1 & 1 & 1 \\
\hline Jumlah & $\mathbf{4 5}$ & & & & $\mathbf{6 . 3 4}$ \\
\hline
\end{tabular}

Cara menghitung $f h$ :

a) Baris pertama 2,7\% x 45=1,22 (dibulatkan menjadi 1)

b) Baris kedua 13,53\% x 45=6,09 (dibulatkan menjadi 6)

c) Baris ketiga $34,13 \%$ x 45=15,36 (dibulatkan menjadi 15)

d) Baris keempat 34,13\% x 45=15,36 (dibulatkan menjadi 15)

e) Baris kelima 13,53\% x 45=6,09 (dibulatkan menjadi 6)

f) Baris keenam 2,7\% x 45=1,22 (dibulatkan menjadi 1)

Dari perhitungan chi kuadrat tersebut diperoleh nilai 6,34. Kemudian dikonsultasikan dengan chi kuadrat $\left(\chi_{\text {tabel }}^{2}\right)$ tabel pada $\mathrm{db}$ 6-1 pada taraf signifikansi $5 \%$ diperoleh 11,070 . Karena harga $\chi_{\text {hitung }}^{2}$ $(6,34)<\chi_{\text {tabe }}^{2}(11.070)$ maka data hasil belajar mata pelajaran fiqh pada kelas yang menggunakan strategi pembelajaran point counterpoint (kelas eksperimen) berdistribusi normal. 


\section{b. Uji Homogenitas}

Pengujian homogenitas varians menggunakan uji $\mathrm{F}$ dengan rumus:

$$
\mathrm{F}=\frac{\text { varian terbesar }}{\text { varian terkecil }}
$$

\section{Dimana:}

$F$ adalah nilai yang dicari

Varian adalah kuadrat dari simpangan baku

Berdasarkan data yang diperoleh diketahui bahwa:

Varians terbesar : 20,01 dengan n: 45

Varians terkecil : 13,75 dengan n: 45

Selanjutnya dicari harga $\mathrm{F}$ dengan menggunakan rumus diatas:

$$
\begin{aligned}
& \mathrm{F}=\frac{\text { varian terbesar }}{\text { varian terkecil }} \\
& F=\frac{21,01}{13,75}=1,53
\end{aligned}
$$

Terakhir harga $F_{\text {hitung }}$ dibandingkan dengan $\mathrm{F}_{\text {tabel }}$ dengan dk pembilang $45-1=44$ dan dk penyebut $45-1=44$ pada taraf signifikansi $5 \%$ diperoleh
1,66 (harga antara pembilang 44 dan 44). Karena $F_{\text {hitung }}(1,53)$ $<\mathrm{F}_{\text {tabel }}(1,66)$ maka varians data homogen.

\section{c. Uji Keseimbangan}

Uji keseimbangan dengan menggunakan rumus sebagai berikut:

$$
t=\frac{\bar{x}_{1}-\bar{x}_{2}}{\sqrt{\frac{s_{1}^{2}}{n_{1}}+\frac{s_{2}^{2}}{n_{2}}}} \quad s^{2}=\frac{\left[\sum \mathrm{x}_{1}^{2}-\frac{\left(\sum \mathrm{x}_{1}\right)^{2}}{\mathrm{n}_{1}}\right]+\left[\sum \mathrm{x}_{2}^{2}-\frac{\left(\sum \mathrm{x}_{2}\right)^{2}}{\mathrm{n}_{2}}\right]}{n_{1}+n_{2}-2}
$$

Dimana:

$\mathrm{t}$ : Nilai $\mathrm{t}$ yang dihitung

$\bar{x}$ Rata - rata $\mathrm{x}$

s2 : Varian

$\mathrm{n}$ : Jumlah anggota sampel

$\bar{x}_{1}=\frac{f x_{1}}{n}=\frac{2483}{45}=55,18$

$\bar{x}_{2}=\frac{f x_{2}}{n}=\frac{2463}{45}=54,73$ 


$$
\begin{aligned}
& s^{2}=\frac{\left[\sum \mathrm{x}_{1}^{2}-\frac{\left(\sum \mathrm{x}_{1}\right)^{2}}{\mathrm{n}_{1}}\right]+\left[\sum \mathrm{x}_{2}^{2}-\frac{\left(\sum \mathrm{x}_{2}\right)^{2}}{\mathrm{n}_{2}}\right]}{\mathrm{n}_{1}} \\
& s^{2}=\frac{\left[648853-\frac{\left.n_{(24}+n_{32}\right)^{2}}{45}\right]^{2}+\left[580477-\frac{(2463)^{2}}{45}\right]}{45+45-2}
\end{aligned}
$$

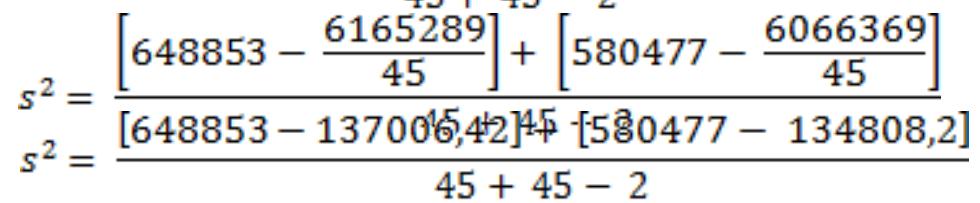

$$
\begin{aligned}
& s^{2}=\frac{[511846,58]+[445668,8]}{88} \\
& s^{2}=\frac{957515,38}{88}=10880,86 \\
& t=\frac{\bar{x}_{1}-\bar{x}_{2}}{\sqrt{\frac{s_{1}^{2}}{n_{1}}+\frac{s_{2}^{2}}{n_{18}}-54,73}} \\
& t=\frac{\sqrt{\frac{150,44}{45}}+\frac{1080,86}{\sqrt{241,79+241,79}}}{\sqrt{0,44}} \\
& t=\frac{0,44}{\sqrt{483,59}}=\frac{0,44}{21,99}=0,02
\end{aligned}
$$

Perhitungan tersebut diperoleh nilai thitung 0,02 kemudian dikonsultasikan dengan harga ttabel pada $\mathrm{dk}=45+45-2=$ 88 pada taraf singnifikan $5 \%$ diperoleh 2,000. Karena harga thitung $(0,02)<$ ttabel $(2,000)$ maka Ho diterima dan $\mathrm{Ha}$ ditolak, ini menunjukkan bahwa tidak ada perbedaan kemampuan antara kedua sampel dalam arti lain bahwa kedua sampel mempunyai kemampuan yang sama (keadaan seimbang). Dengan demikian dapat dikatakan bahwa nilai yang ditunjukkan oleh hasil eksperimen benarbenar berdasarkan perlakuan yang dilakukan peneliti.

\section{Pengujian hipotesis}

Hipotesis merupakan jawaban sementara atas masalah yang harus dirumuskan. Hipotesis ini harus diteliti kebenarannya secara empiris, dalam penelitian ini terdiri dari dua macam hipotesis yaitu hipotesis nihil (Ho) yaitu hipotesis yang menyatakan tidak adanya perbedaan antara variabel satu dengan yang lain. Sedangkan hipotesis alternatif (Ha) yaitu hipotesis yang 
menyatakan adanya perbedaan antara variabel satu dengan yang lainnya.
Pengujian hipotesis dilakukan menggunakan uji t-test dengan rumus:

$$
t=\frac{\bar{x}_{1}-\bar{x}_{2}}{\sqrt{\frac{s_{1}^{2}}{n_{1}}+\frac{s_{2}^{2}}{n_{2}}-2 r\left(\frac{s_{1}}{\sqrt{n_{1}}}\right)\left(\frac{s_{2}}{\sqrt{n_{2}}}\right)}}
$$

Dimana:
$\mathrm{x}_{1}$ : Rata-rata sampel 1
$\mathrm{s}_{1}^{2}$ : Varian sampel 1
$\mathrm{x}_{2}$ : Rata-rata sampel 2
$\mathrm{s}_{1}{ }^{2}$ : Varian sampel 2
$\mathrm{n}_{1}$ : Jumlah sampel 1
$\mathrm{r}$ : Koefisien korelasi kedua sampel
$\mathrm{n}_{2}$ : Jumlah sampel 2
Dari hasil perhitungan diketahui:

$\begin{array}{llll}\mathrm{x}_{1} & =14,60 & \mathrm{x}_{2} & =18,61 \\ \mathrm{~s}_{1} & =3,71 & \mathrm{~s}_{2} & =4,58 \\ \mathrm{~s}_{1}{ }^{2} & =13,76 & \mathrm{~s}_{2}{ }^{2} & =21,01 \\ \mathrm{n}_{1} & =45 & \mathrm{n}_{2} & =45 \\ \mathrm{r} & =0,373 & & \end{array}$

$$
\begin{aligned}
& t=\frac{\bar{x}_{1}-\bar{x}_{2}}{\sqrt{\frac{s_{1}^{2}}{n_{1}}+\frac{s_{2}^{2}}{n_{2}}-2 r\left(\frac{s_{1}}{\sqrt{n_{1}}}\right)\left(\frac{s_{2}}{\sqrt{n_{2}}}\right)}} \\
& t=\frac{14,60-18,61}{\sqrt{\frac{13,76}{45}+\frac{21,01}{45}-2(0,373)\left(\frac{3,71}{6,708}\right)\left(\frac{4,58}{6,708}\right)}} \\
& t=\frac{-4,01}{\sqrt{0,306+0,467-(0,746)(0,553)(0,683)}} \\
& t=\frac{-4,01}{\sqrt{0,492}}=-5,721
\end{aligned}
$$

Perhitungan tersebut diperoleh nilai thitung $\quad 5,721$ kemudian dikonsultasikan dengan harga ttabel pada $\mathrm{dk}=45+45-2=88$ pada taraf singnifikan 5\% diperoleh 2,000. Karena harga thitung $(5,721)>$ tabel $(2,000)$ maka dapat dikatakan bahwa ada perbedaan pada hasil belajar mata pelajaran fiqh antara yang menggunakan strategi pembelajaran point counterpoint pada siswa kelas eksperimen dengan metode konvesional pada siswa kelas kontrol. 
Pengaruh Strategi Pembelajaran Point Counterpoint

Terhadap Hasil Belajar Mata Pelajaran Figh Siswa

MAN Karanggede Tahun 2014/2015

\section{PEMBAHASAN}

Berdasarkan penelitian yang telah dilaksanakan dengan menggunakan skala 1:3,33 diperoleh data hasil belajar mata pelajaran fiqh siswa yang menggunakan metode konvensional pada kelas kontrol didapatkan skor tertinggi 24, skor terendah 7, dan rentang (range) sebesar 17. Perhitungan yang dilakukan terhadap hasil tes didapatkan mean 14,60, median 14,28, modus 13,88 dan standar deviasi 3,71. Dari perhitungan tersebut didapatkan kategori tinggi mencapai $15,56 \%$ yang terletak pada interval 19-24 dengan jumlah 7 siswa, katagori sedang mencapai $55,56 \%$ yang terletak pada interval 13-18 dengan jumlah 25 siswa, dan katagori rendah mencapai $28,89 \%$ yang terletak pada interval 7-12 dengan jumlah 13 siswa. Hasil ini menunjukkan bahwa hasil belajar mata pelajaran fiqh yang menggunakan metode konvensional pada kelas kontrol berada dalam katagori sedang.

Sementara hasil belajar mata pelajaran fiqh siswa yang menggunakan strategi pembelajaran point counterpoint pada kelas eksperimen didapatkan skor tertinggi 28, skor terendah 6 , dan rentang (range) sebesar 22. Perhitungan yang dilakukan terhadap hasil tes didapatkan mean 18,61, median 19,03, modus 19,63 dan standar deviasi 4,58. Dari perhitungan tersebut didapatkan kategori tinggi mencapai $26,67 \%$ yang terletak pada interval 22-29 dengan jumlah 12 siswa, katagori sedang mencapai $57,78 \%$ yang terletak pada interval 14-21 dengan jumlah 26 siswa, dan katagori rendah mencapai
$15,56 \%$ yang terletak pada interval 6-13 dengan jumlah 7 siswa. Hasil ini menunjukkan bahwa hasil belajar mata pelajaran fiqh yang menggunakan strategi pembelajaran point counterpoint pada kelas eksperimen berada dalam katagori sedang.

Berdasarkan hasil perhitungan diperoleh nilai thitung $(5,721)$ kemudiam dikonsultasikan dengan $\mathrm{dk}=88$ pada taraf signifikansi 5\% diperoleh 2,000. Karena harga thitung $(5,721)>$ ttabel $(2,000)$ maka terdapat perbedaan pada hasil belajar mata pelajaran fiqh antara yang menggunakan strategi pembelajaran point counterpoint pada siswa kelas eksperimen dengan metode konvesional pada siswa kelas kontrol.

Dari proses perhitungan statistika diperoleh rata-rata kelas kontrol (kelas yang menggunakan metode konvensional) adalah 14,60 sedangkan rata-rata kelas eksperimen (kelas yang menggunakan strategi pembelajaran point counterpoint) adalah 18,61. Dari rata-rata tersebut menunjukkan perbedaan sebesar 4,01 yang membuktikan bahwa strategi pembelajaran point counterpoint mempunyai peran dalam meningkatkan hasil belajar mata pelajaran fiqh pada siswa MAN Karanggede.

Adapun perbedaan perbandingan hasil belajar mata pelajaran fiqh antara kelas kontrol dan kelas eksperimen dapat dilihat pada tabel berikut: 
Tabel 7

Perbedaan Perbandingan Hasil Belajar Mata Pelajaran Fiqh antara Kelas Kontrol dan Kelas Eksperimen

\begin{tabular}{|c|c|c|c|c|c|c|c|c|c|c|}
\hline \multicolumn{5}{|c|}{ Kelas Kontrol } & \multicolumn{5}{|c|}{ Kelas Eksperimen } & \multirow[b]{2}{*}{ Katagori } \\
\hline Interval & $\mathrm{F}$ & FK & Persnte & $\begin{array}{l}\text { Persnte- } \\
\text { kum }\end{array}$ & Interval & $\mathrm{F}$ & FK & Persnte & $\begin{array}{l}\text { Persnte- } \\
\text { kum }\end{array}$ & \\
\hline $7-9$ & 3 & 3 & $6,67 \%$ & \multirow{2}{*}{$28,89 \%$} & $6-9$ & 1 & 1 & $2.22 \%$ & \multirow[t]{2}{*}{$15.56 \%$} & \multirow{2}{*}{ Rendah } \\
\hline $10-12$ & 10 & 13 & $22,22 \%$ & & $10-13$ & 6 & 7 & $13.33 \%$ & & \\
\hline $13-15$ & 16 & 29 & $35,56 \%$ & \multirow{2}{*}{$55,56 \%$} & $14-17$ & 9 & 16 & $20.00 \%$ & \multirow{2}{*}{$57.78 \%$} & \multirow{2}{*}{ Sedang } \\
\hline $16-18$ & 9 & 38 & $20,00 \%$ & & $18-21$ & 17 & 33 & $37.78 \%$ & & \\
\hline $19-21$ & 5 & 43 & $11,11 \%$ & \multirow{2}{*}{$15,56 \%$} & $22-25$ & 10 & 43 & $22.22 \%$ & \multirow[t]{2}{*}{$26.67 \%$} & \multirow{2}{*}{ Tinggi } \\
\hline $22-24$ & 2 & 45 & $4,44 \%$ & & $26-29$ & 2 & 45 & $4.44 \%$ & & \\
\hline & 45 & & $100,00 \%$ & $100,00 \%$ & & 45 & & $100.00 \%$ & $100.00 \%$ & \\
\hline
\end{tabular}

Dari tabel diatas menunjukkan bahwa strategi pembelajaran point counterpoint memberikan perubahan terhadap hasil belajar mata pelajaran fiqh siswa MAN Karanggede. Hal itu dapat dilihat dari hasil persentase kumulatif keduanya yang menunjukkan tingkat penurunan dalam katagori rendah dari 28,89\% menjadi $15,56 \%$ dengan jumlah dari 13 siswa menjadi 7 siswa. Diikuti juga kenaikan persentase kumulatif katagori tingkat tinggi dari $15,56 \%$ menjadi 26,67\% dengan jumlah 7 siswa menjadi 12 siswa. Selain itu dapat juga dilihat adanya perubahan tingkat kelas dalam katagori sedang yaitu pada kelas kontrol nilai dominan terletak pada tingkat kelas ketiga dengan interval 13-15 dan tingkat persentase $35,56 \%$ (16 siswa) sedangkan pada kelas eksperimen didominasi pada tingkat kelas keempat dengan interval 18-21 dan tingkat persentase $37,78 \%$ (17 siswa).

Dari hasil tersebut menunjukkan bahwa ada pengaruh strategi pembelajaran point counterpoint terhadap hasil belajar mata pelajaran fiqh siswa MAN Karanggede dengan bukti perbedaan-perbedaan nilai antara kelas kontrol dengan kelas eksperimen walaupun perbedaan tersebut tidak begitu signifikan.

\section{PENUTUP}

Kesimpulan dalam penelitian ini adalah gambaran hasil belajar mata pelajaran fiqh pada kelas kontrol mencapai nilai rata-rata 14,60 dan menunjukkan adanya tingkat hasil belajar pada katagori sedang yaitu sebanyak 16 siswa atau $35,56 \%$ yang terletak pada tingkat kelas ketiga dengan interval 13-15. Gambaran hasil belajar mata pelajaran fiqh pada kelas eksperimen mencapai nilai rata-rata 18,61 dan menunjukkan adanya tingkat hasil belajar pada katagori sedang yaitu sebanyak 17 siswa atau 37,78\% yang terletak pada tingkat kelas keempat dengan interval 1821. Sedangkan hasil uji beda variabel tingkat hasil belajar fiqh pada kelas kontrol dengan kelas eksperimen didapat $t_{\text {hitung }}$ $(5,721)>t_{\text {tabel }}(2,000)$ sehingga Ho ditolak dan Ha diterima, artinya terdapat perbedaan 
Pengaruh Strategi Pembelajaran Point Counterpoint

Terhadap Hasil Belajar Mata Pelajaran Fiqh Siswa

MAN Karanggede Tahun 2014/2015

hasil belajar mata pelajaran fiqh antara kelas yang menggunakan metode konvensional dengan kelas yang menggunakan strategi pembelajaran point counterpoint siswa MAN Karanggede tahun pelajaran 2014/2015 dengan kata lain ada pengaruh strategi

\section{DAFTAR PUSTAKA}

Ahmad Sabri. 2007. Strategi Belajar Mengajar dan Micro Teaching. Ciputut: Ciputut Press.

Asep Jihad dan Abdul Haris, 2008. Evaluasi Pembelajaran. Yogyakarta: Multi Pressindo.

Darmasyah. 2010. Startegi Pembelajara Menyenagkan dengan Humor. Jakarta: bumi aksara.

Departemen Agama Republik Indonesia. 2005. Mushaf Alquran Terjemah. Jakarta: Al Huda.

Departemen Agama Republik Indonesia. 2007: Standar Kompetensi Lulusan (SKL), Standar Kompetensi (SK) dan Kompetensi Dasar (KD).

Eko Putro Widoyoko. 2009. Evaluasi Program Pembelajaran. Yogyakarta: Pustaka Pelajar.

Hamruni. 2009. Strategi Dan Model-Model Pembelajaran Aktif Menyenangkan. Yogyakarta: Fakultas Tarbiyah UIN Sunan Kalijaga Yogyakarta.

Imam Makruf. 2006. At Tarbawi (Pengembangan Strategi Belajar di
ISSN : 2477-6157

PTAI dalam Mewujudkan Kompetensi Lulusan). Sukoharjo: Jurusan Tarbiyah STAIN Surakarta. Vol.4

Mel Silbermen. 2009. Active Learning 101 Startegi Pembelajaran Aktif. Yogyakarta: Pustaka Insan Madani

Michael dan Jude Kaye. 2005. Perencanaan Strategi. Jakarta: Remaja Rosdakarya.

Nana Sudjana dan Ibrahim. 2004. Penilaian Hasil Proses Belajar Mengajar. Bandung: PT remaja.

Nana Syaodih Sukamdinata. 2003. Landasan Psikologi Proses Belajar. Bandung: Remaja Rosdakarya.

Nanang Hanafiah dan Cucu Suhana, 2009. Konsep Strategi Pembelajaran. Bandung: Refika Aditama.

Purwanto. 2007. Instrumen Penelitian Sosial dan Pendidikan. Yogyakarta: Pustaka Pelajar . 2008. Evaluasi Hasil Belajar. Yogyakarta: Pustaka Pelajar

Riduwan. 2007. Belajar Mudah Penelitian Untuk Guru-Karyawan dan Peneliti Pemula. Bandung: Alfabeta.

Roestijah. 2008. Strategi Belajar Mengajar. Jakarta: Rineka Cipta.

Santi Siska. 2011. Penerapan Strategi Belajar Murder (Mood, Understand, Recall, Digest, Expand, Review dalam Meningkatkan Pemahaman Peserta 
didik pada Mata Pelajaran Fiqh. Surakarta.

Slameto. 2003. Belajar dan Faktor-Faktor yang Mempengaruhinya. Jakarta: Rineka Cipta

Subana dan Moersetyo Rahadi. 2005. Statistik Pendidikan. Bandung: Pustaka Setia

Sugiyono. 2007. Statistik untuk Penelitian. Bandung: Alfabeta.

2007. Metode Penelitian Administrasi. Bandung: Alfabeta.

Suharsimi Arikunto. 2006. Prosedur Penelitian Suatu Pendekatan Praktek. Jakarta: Rineka Cipta.

Syafarudin dan Irwan Nasution. 2005. Manajemen Pembelajaran. Jakarta: Quantum teaching.

Veihzal Rivai dan Syiviana Murni. 2009. Education Management. Jakarta: Grafindo Persada.

W. Gulo. 2002. Strategi Belajar Mengajar. Jakarta: Presindo.

Wina Sanjaya. 2008. Perencanaan dan Desain Sistem Pembelajaran. Jakarta: Kencana Prenada Media Grup

Yanvita. 2007. Perbedaan Prestasi Belajar PAI antara yang Menggunakan Metode Ceramah dengan Strategi Card Sort. Surakarta

Yusuf Rohmadi. 2006. At Tarbawi (UU Guru dan Dosen serta Peningkatan Mutu Pendidikan). Sukoharjo:
Jurusan Tarbiyah STAIN Surakarta. Vol.4 